\section{'The child is father of the man'-why we need to ask adults about their childhood}

\author{
John Launer
}

Last December the Fellowship of Postgraduate Medicine held a conference at the Royal College of Physicians of London, marking the centenary of the death of Sir William Osler. One of the main presentations in the morning was by Professor Neena Modi, former president of the Royal College of Paediatrics and Child Health, and now president of the Medical Women's Federation. She spoke about research into the links between premature birth and disease in adult life. She also drew attention to how unusual it is for a paediatrician to be addressing an audience made up largely of physicians working with older patients, and she made a strong case for them to become more curious, and better informed, about how early life might affect the grown-ups they see every day in their consulting rooms and on the wards.

Professor Modi and co-author Emily Prior now make the same case in a paper in this month's Postgraduate Medical Journal. ${ }^{1}$ As they show, the facts about the enduring medical impact of premature birth are alarming. To summarise, prematurity is associated with a mean increase in systolic blood pressure of $4.2 \mathrm{mmHg}$, and in diastolic pressure of $2.6 \mathrm{mmHg}$. Lean body mass is lower and internal abdominal adipose tissue is higher. There is evidence for preterm birth as an independent risk factor for type two diabetes, ischaemic heart disease, heart failure and chronic kidney disease, while birth before 32 weeks is associated with a nearly twofold increased risk of cerebrovascular disease. Preterm adults show evidence of disruption to every organ system, have biomarkers of increased risk of late-life onset disorders, and (in men) a higher proportion of short telomeres - a molecular correlate of accelerated ageing. Overall, gestational age at birth is inversely associated with mortality from infancy to adulthood. Social disadvantage may compound matters, not only by making prematurity more likely, but further adding to the likelihood of

Associate Editor, Postgraduate Medical Journal, London, UK

Correspondence to Dr John Launer, London, UK; johnlauner@aol.com these diseases later. The main lesson to learn from all of this is that neonatal practice offers a crucial opportunity to improve lifelong health. Another lesson, in Professor Modi's own words, is: "Ask about birth gestational age when taking a medical history!"

\section{ADVERSE CHILDHOOD EVENTS}

If there are good reasons for physicians to ask about the beginning of life, there are surely similar reasons why they should extend their curiosity into later childhood history too. In particular, there has been evidence for over twenty years of a relationship between exposure to adverse childhood experiences (ACEs) and risk factors for several of the leading causes of death in adulthood. ${ }^{2}$ (ACEs are generally regarded as verbal, physical and sexual abuse, physical or emotional neglect, parental separation, household mental illness or domestic violence, and alcohol or drug abuse. ${ }^{3}$ ) As a systematic review in the Lancet showed, there are significant links between multiple ACEs and cancer, heart and respiratory disease. ${ }^{4}$ There are even stronger associations with violence, self-harm and mental ill health in adulthood, together with sexual risk-taking, and problematic drug and alcohol use.

One consequence of such research has been the emergence of an entirely different approach towards many patients with multiple or intractable medical problems: trauma-informed care. ${ }^{5}$ Such care entails recognising that traumatic childhood experiences can have long-term impacts on brain development, physiology, and behaviour. Through epigenetic effects, ACEs can alter that way genes operate, affecting neural connections in the brain. It can impact on the immune system, making people more vulnerable to some diseases. At a psychological level, it can affect the way people perceive pleasure and reward, leading to difficulty in regulating emotion, along with persistent anxiety or addiction. While conventional care tends to concentrate on medical and psychiatric problems separately or in terms of distinct diagnoses, trauma-informed care focuses on the lifelong picture, and on developing an understanding of this, in both patient and physician.

\section{TRAUMA IS EMBODIED}

One doctor who has shown a particular interest in practising and teaching traumainformed care is the East London general practitioner (GP) Jonathon Tomlinson. ${ }^{6}$ He describes how, like many experienced GPs, he finds himself spending most of his time nowadays with patients who suffer from "chronic pain, medically unexplained symptoms, addiction, eating disorders, severe obesity, self-harm, suicidal thoughts and mental health disorders; especially chronic anxiety, chronic depression, OCD (Obsessive-Compulsive Disorder), bipolar and personality disorders." Among these are also the patients with the worst diabetic complications, the most symptomatic heart failure, the most brittle asthma and out of control hypertension. They are also the same ones who attend accident and emergency departments most often and are likely to fail to turn up to out-patient reviews.

Over time, Tomlinson explains, he has learnt that many people of these people are survivors of multiple ACEs. For them, trauma is embodied: it expresses itself as a fear of the world as a dangerous place, a propensity to disconnect from aspects of themselves, and an identity that has become rooted in shame at what they have become. For some of these people, their GP is "the only emotionally stable adult" in their lives. In common with others whose work he draws on, ${ }^{7-9}$ Tomlinson has found that the first step towards recovery for many of his patients is for him to offer the one important thing they have hitherto lacked: trust. He believes this a crucial role for GPs, but also something that all doctors need to be sensitised to. He writes:

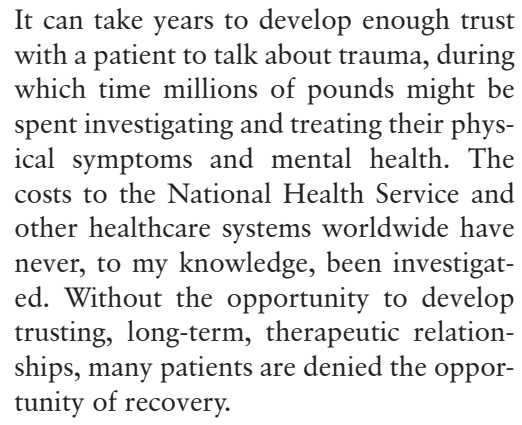

\section{TRANSFORMING PRACTICE}

As Tomlinson makes clear, trauma is just one of several contributory factors leading to many diseases and there is also no single treatment. Since trauma affects both 
body and mind together, it often requires approaches that attend to both. At the same time, he emphasises that learning about trauma has completely transformed his practice, helping him to make sense of a great deal that had frustrated, worried and exhausted him for years. He also makes the point that it is more important to acknowledge that "stuff happened" than it is to know exactly what it was, that trust and safety have to come first, and that a lack of protective factors (attachment, love, consistency, safety and so on) can be just as traumatic as the presence of ACEs.

"The child is father of the man," wrote the poet William Wordsworth, describing how his inner child had remained within him as an adult. ${ }^{10}$ In his case, he was describing an experience of pure joy: how seeing a rainbow had delighted him when he was small, still did so as a grown-up, and he hoped would continue to do when he was old. For many of the people we see - fathers and mothers, men and women - their prospects for a long or joyful life may have been impaired early on. When we encounter them as adults, we need to ask them about their childhood.

Twitter John Launer @JohnLauner

Acknowledgements I am grateful to Professor Neena Modi for sharing her presentation and to Dr Jonathon Tomlinson for helpful suggestions on an earlier draft of this article.

Funding The authors have not declared a specific grant for this research from any funding agency in the public, commercial or not-for-profit sectors.

Competing interests None declared.

Patient consent for publication Not required.

Provenance and peer review Not commissioned; internally peer reviewed.

(c) Author(s) (or their employer(s)) 2020. No commercial re-use. See rights and permissions. Published by BMJ.

\section{Check for updates}

To cite Launer J. Postgrad Med J 2020;96:447-448.

Postgrad Med J 2020;96:447-448.

doi:10.1136/postgradmedj-2020-138170

\section{REFERENCES}

1 Prior E, Modi N. Adult outcomes after preterm birth. Postgrad Med I 2000.
2 Felitti VJ, Anda RF, Nordenberg D, et al. Relationship of childhood abuse and household dysfunction to many of the leading causes of death in adults. The adverse childhood experiences (ACE) study. Am J Prev Med 1998;14:245-58.

3 Hughes K, Ford K, Davies A, et al. Sources of resilience and their moderating relationships with harms from adverse childhood experiences. Bangor: Public Health Wales/lechyd Cyhoeddus Cymru, 2018.

4 Hughes K, Bellis MA, Hardcastle KA, et al. The effect of multiple adverse childhood experiences on health: a systematic review and meta-analysis. Lancet Public Health 2017;2:e356-66.

5 Fenney D. Tackling poor health outcomes: the role of trauma-informed care, 2019. Available: https://www. kingsfund.org.uk/blog/2019/11/trauma-informed-care [Accessed 2 May 2020].

6 Tomlinson J. We need to talk about trauma, 2017. Available: https://abetternhs.net/2017/10/15/we-needto-talk-about-trauma/ [Accessed 2 May 2020].

7 Herman J. Trauma and recovery: the aftermath of violence - from domestic violence to political terror. New York, NY: Basic Books, 1992.

8 van der Kolk B. The body keeps the score: mind, brain and body in the transformation of trauma. New York, NY: Penguin, 2015.

9 Sieff D. Understanding and healing emotional trauma: Conversations with pioneering clinicians and researchers. Abingdon: Routledge, 2014.

10 Wordsworth W. My heart leaps up. Poems, in two volumes. London: Longman, Hurst, Rees and Orme, 1807: vol.2. 44. https://poets.org/poem/my-heart-leaps 